\title{
SPESIES ULAT KANTONG DAN MUSUH ALAMINYA YANG BERASOSIASI DENGAN TANAMAN SENGON (Falcataria moluccana (Miq.) Barneby \& J.W. Grimes) \\ (Bagworms and Their Natural Enemies Associated with Albizia (Falcataria moluccana (Miq.) Barneby \& J.W. Grimes plantation)
}

\author{
Ujang Wawan Darmawan ${ }^{1 *}$, Hermanu Triwidodo² ${ }^{2}$ Purnama Hidayat $^{2}$, \\ Noor Farikhah Haneda ${ }^{2}$, dan/and Neo Endra Lelana ${ }^{1}$ \\ ${ }^{1}$ Pusat Penelitian dan Pengembangan Hutan \\ Jl. Gunung Batu No.5 Po Box 165 Bogor, Jawa Barat, Indonesia \\ Telp. 0251-8633234; Fax 0251-8638111 \\ ${ }^{2}$ Institut Pertanian Bogor \\ J1. Raya Darmaga Bogor 16680, Jawa Barat, Indonesia \\ Tlp./Fax: (0251) 8621947 \\ *Email: ujdarmawan@ymail.com
}

Tanggal diterima: 12 September 2019; Tanggal direvisi: 18 Maret 2020; Tanggal disetujui: 9 April 2020

\begin{abstract}
Bagworms are reported as severe pests in albizia in some areas. The bagworms species that attacked the plant in Java had been identified but had not been described well. Their natural enemies also had not been identified in this area. This information is essential and related to pest control opportunities. This study described several species of bagworm and their natural enemies. It also described the characters of the bag as a marker of the bagworm type. Samples were collected from ten localities spread across Central and West Java. Bagworms pupae were collected and reared so that the imago or natural enemies emerged. The parasitization rate against bagworm pupae was then determined. Imago and natural enemies were morphologically described, as are bags character. Four species of bagworm were associated with albizia stand, namely Pteroma plagiophleps, Chalia javana, Clania crameri, and Khopene cuprea. Description and desk study revealed synonymies among bagworm species. Morphologically, a bagworm species had a unique characteristic bag as a type in shape, pattern, and size. Natural enemies were commonly parasitic Hymenoptera and Diptera insects and entomopathogenic fungi. The bagworm species has been associated with a particular insect of the parasitoid. The many synonyms in the particular species need to be confirmed through a comprehensive depth study involving morphological (imago, bag, and larvae) and molecular approaches to overcome synonymies among bagworm species.
\end{abstract}

Keywords: Description, entomopathogen, parasitoid, Pteroma plagiophleps, bag size

\begin{abstract}
ABSTRAK
Ulat kantong sebagai hama serius pada sengon di beberapa daerah. Spesies ulat kantong yang menyerang sengon di Pulau Jawa sudah pernah diidentifikasi tetapi belum dideskripsikan dengan baik. Musuh alami ulat kantongnya juga belum pernah diidentifikasi. Informasi ini penting karena terkait peluang pengendaliannya. Tujuan penelitian untuk mendeskripsikan beberapa spesies ulat kantong yang menyerang sengon dan musuh alami yang berasosiasi dengannya serta mendeskripsikan karakter kantong sebagai penanda spesiesnya. Sampel diambil dari sepuluh lokasi yang tersebar di Jawa Tengah dan Jawa Barat. Pupa ulat kantong dikumpulkan, dipelihara, sehingga imago atau musuh alami keluar dan tingkat parasitisasi ditentukan. Imago dan musuh alami
\end{abstract}


dideskripsikan secara morfologi, demikian juga dengan karakter kantongnya. Empat spesies ulat kantong teridentifikasi berasosiasi dengan sengon adalah Pteroma plagiophleps, Chalia javana, Clania crameri, dan Khopene cuprea. Deskripsi dan penelusuran pustaka menunjukkan banyaknya nama sinonim yang terkait spesies-spesies tersebut. Secara morfologi, setiap spesies ulat kantong memiliki karakter kantong yang khas baik bentuk, pola maupun ukurannya. Musuh alami ulat kantong umumnya adalah serangga Hymenoptera dan Diptera serta cendawan entomopatogen. Adanya asosiasi spesies ulat kantong dengan spesies parasitoid tertentu. Banyaknya sinonim pada spesies ulat kantong perlu dikonfirmasi melalui pendekatan yang komprehensif dengan menggabungkan metode berbasis morfologi (imago, kantong, dan larva) sekaligus molekuler.

\section{Kata kunci: Deskripsi, entomopatogen, parasitoid, Pteroma plagiophleps, ukuran kantong}

\section{PENDAHULUAN}

Sengon Falcataria moluccana (Miq.) Barneby \& J.W. Grimes merupakan komoditas kehutanan penghasil kayu yang penting. Kayu sengon sebagian besar dihasilkan dari Pulau Jawa (BPS, 2019). Serangan hama ulat kantong pada tanaman ini di Indonesia dilaporkan pernah mengalami ledakan populasi (Lelana \& Anggraeni, 2012).

Informasi tentang spesies ulat kantong yang menyerang sengon merupakan hal penting karena terkait dengan potensi dampak yang ditimbulkan. Identifikasi dan deskripsi ulat kantong biasanya didasarkan dari imagonya. Selain berfungsi sebagai pelindung yang baik terhadap predatornya (Sugiura, 2016) atau kondisi lingkungan yang buruk (Frank, 2015), karakteristik kantong merupakan penanda yang khas dan bervariasi antar taksa (Usha \& Jose, 2018), sehingga dapat digunakan sebagai penanda spesiesnya.

Selain informasi spesiesnya, peran musuh alaminya merupakan hal penting. Peran musuh alaminya menentukan populasi dan dampak serangan ulat kantong bagi tanaman. Parasitisasi musuh alami pada ulat kantong dapat mencapai 39,2\% (Potineni \& Saravanan, 2013).

Spesies ulat kantong yang berasosiasi dengan sengon di Pulau Jawa pernah dipublikasikan, namun belum dideskripsikan secara lengkap (Setyawan,
Hidayat, \& Puliafico, 2018). Selain itu, informasi musuh alaminya juga belum pernah dipublikasikan. Penelitian ini bertujuan untuk mendeskripsikan spesies ulat kantong beserta musuh alaminya yang menyerang sengon beserta tingkat parasitisasinya. Karakter kantong juga dideskripsikan sebagai karakter tambahan untuk identifikasinya.

\section{METODOLOGI}

\section{A. Waktu dan Lokasi Penelitian}

Sampel berupa pupa ulat kantong dikoleksi dari tegakan sengon monokultur di berbagai lokasi, yaitu Kabupaten Pekalongan, Batang, Subang, Kota dan Kabupaten Bogor, pada bulan Oktober 2018 sampai Februari 2019. Tegakan sengon yang ada merupakan tegakan berumur 1-4 tahun yang berada pada ketinggian 200-500 m dari permukaan laut (dpl).

\section{B. Metode}

\section{Pengambilan sampel uji}

Pada masing-masing tegakan sengon tersebut, dipilih lima tanaman yang terserang dan tersebar merata sebagai pohon sampel. Berdasarkan studi pendahuluan, spesies ulat kantong yang populasinya tinggi adalah Pteroma plagiophleps. Pengamatan terhadap 
spesies ini dilakukan dengan cara membagi pohon menjadi tiga bagian tajuk. Tajuk setiap pohon yang dipilih secara acak, kemudian dibagi menjadi tiga tingkat yaitu bagian bawah, tengah, dan atas. Pada masing- masing tingkat tajuk tersebut, diambil satu buah ranting sepanjang satu meter dari ujung. Pengamatan populasi dilakukan pada tiga bagian yaitu pada satu helai daun majemuk bagian ujung (daun kedua dari pucuk yang telah terbuka sempurna), satu helai daun majemuk bagian tengah (daun keempat dari pucuk), dan pada ranting tanpa daun sepanjang satu meter tersebut. Adapun spesies ulat kantong yang jumlah populasinya rendah diamati dengan cara mengambil semua sampel pupa pada pohon tersebut.

\section{Pemeliharaan}

Pupa yang berhasil dikumpulkan kemudian dipelihara pada botol plastik transparan berukuran $30 \mathrm{ml}$ atau lebih besar (tergantung ukuran pupa) dan ditutup rapat. Sebelumnya, bagian tutup botol tersebut telah dimodifikasi dengan membuat sebuah lubang berupa lingkaran berukuran diameter $0,5 \mathrm{~mm}$ dibuat dan ditutup menggunakan kain organdi. Lubang ini berfungsi untuk mengalirkan udara bagi pupa di dalam botol. Pengamatan terhadap pupa dilakukan setiap hari sampai ngengat atau imago parasitoid muncul ( \pm 4 bulan).

Setelah ngengat atau parasitoid muncul, sedikit kapas yang dibasahi klorofom dimasukkan ke dalam botol dan didiamkan selama beberapa saat. Imago atau parasitoid yang telah mati kemudian diambil secara perlahan menggunakan kuas. Pupa yang mengindikasikan gagal berkembang atau memiliki ciri yang tidak normal kemudian dibedah untuk mengetahui keadaan di dalam kantong tersebut.

Ngengat atau parasitoid yang muncul kemudian disimpan di dalam botol yang berbeda. Ngengat beserta bekas kantong dan pupariumnya disimpan di dalam botol plastik transparan berukuran $30 \mathrm{ml}$ yang di dalamnya juga disertakan desikan. Desikan berfungsi untuk menyerap atau menurunkan kadar air, sehingga spesimen tidak mudah rusak akibat cendawan atau mikroba lain. Bekas kantong dan puparium imago parasitoid juga disimpan di dalam botol serupa, namun imagonya disimpan di dalam botol kaca $30 \mathrm{ml}$ yang Didalamnya berisi alkohol $70 \%$ sebanyak $15 \mathrm{ml}$.

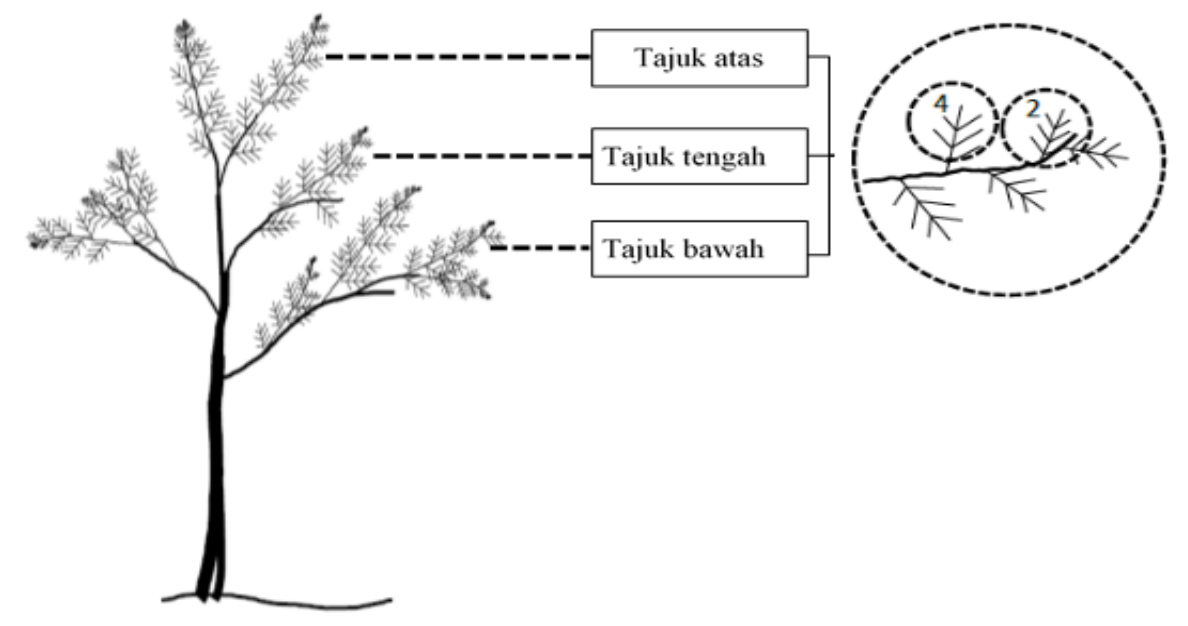

Gambar (Figure) 1. Ilustrasi pengambilan sampel (Illustration of sampling) 


\section{Analisis \\ 1. Identifikasi deskripsi imago ulat kantong}

Ngengat dan imago parasitoid yang muncul diidentifikasi di bawah mikroskop. Referensi terkait dipakai untuk acuan identifikasi yaitu Hyenoptera of the World: An Identification Guide to Families (Brothers et al., 1993). Imago diidentifikasi berdasar ciri morfologi. Hasil identifikasi kemudian dikonfirmasi ke Lembaga Ilmu Pengetahuan Indonesia (LIPI).

Selain itu, karakteristik kantong juga dideskripsikan sebagai penanda beberapa genus (Usha \& Jose, 2018). Deskripsi kantong meliputi karakter warna, ukuran (panjang dan diameter), bentuk dan material penyusun kantong.

\section{Parasitisasi}

Jumlah sampel yang digunakan untuk pengamatan parasitisasi adalah 800 individu untuk spesies ulat kantong yang dominan (Pteroma plagiophleps) dan semua pupa yang berhasil dikumpulkan dari lapangan untuk ulat kantong yang populasinya rendah, yaitu: 258, 24, dan 14 masing-masing untuk (Chalia javana, Clania crameri, dan Kophene cuprea). Tingkat parasitisasi dihitung berdasarkan proporsi jumlah sampel pupa yang terparasit terhadap jumlah total pupa yang dikumpulkan.

$$
\text { Parasitisasi }=\frac{\sum \text { Sampel pupa terparasit }}{\sum \text { Total sampel pupa }}
$$

\section{HASIL DAN PEMBAHASAN}

\section{A. Hasil}

\section{Spesies ulat kantong pada sengon}

Spesies ulat kantong yang menyerang sengon adalah Pteroma plagiophleps Hampson, Chalia javana Heylaerts, Clania crameri Westw., dan Kophene cuprea Moore. Spesies ulat kantong tersebut ditemukan hampir di semua lokasi pengamatan kecuali C. javana tidak ditemukan di Kabupaten Batang dan Kabupaten Subang serta K. cuprea tidak ditemukan di Kabupaten Subang (Tabel 1), Setiap spesies ulat kantong memiliki karakter morfologi imago dan kantong yang khas. Ukuran kantong setiap spesiesnya disajikan pada Tabel 2 sedangkan imago dan karakter kantongnya dideskripsikan sebagai berikut:

\section{a. Pteroma plagiophleps Hampson}

Asal sampel : Pekalongan, Jawa Tengah

Tanggal koleksi : Nopember 2018

Inang : Sengon

Deskripsi : Betina dewasa verminform, antena, tungkai dan embelan lain vestigial, langsing. Jantan dewasa bersayap, kepala, torak dan abdomen ditutupi rambut gelap. Tubuh berwarna coklat gelap polos. Antena bercabang panjang (bipektinet), satu ruas terakhiir tidak bercabang (tunggal), dan dua baris rambut agak jarang di setiap cabangnya. Bentang sayap $15 \mathrm{~mm}$, bagian ventral sayap belakang agak putih mengkilat kebiruan. Abdomen langsing, lebih pendek daripada sayap belakang, berwarna terang, tungkai ditutup rabut terang, tibia tungkai depan duri panjang. Genetalia jantan; uncus agak masuk ke dalam, dengan dua cuping berambut, valva pendek, sempit, sama lebar kemudian agak menyempit dan ujung tumpul. Vinculum sempit dan agak memanjang. Saccus padat berbentuk U, falus pendek, silindris dan ujung membesar berbentuk tidak beraturan (Gambar 2).

Bentuk dasar kantong P. plagiophleps kerucut, cenderung oval. Bagian ujung terpenggal pada bagian tertentu, sehingga tampak tumpul (khususnya pada pupa jantan). Kedudukan kantong menggantung bebas pada ranting, batang, tulang dan helaian anak daun melalui sutera yang terpilin, tersambung ke pangkal kantong, menutup secara perlahan ke bagian tepi pangkal, berbentuk oval. Kantong berupa 
lapisan yang tidak terlalu keras, sutera yang bercampur substrat berbentuk pipih, terkesan kasar, warna dasar kecoklatan.

\section{b. Chalia javana Heylaerts}

Asal sampel : Bogor, Jawa Barat

Tanggal koleksi : Januari 2019

Inang : Sengon

Deskripsi : Kepala, torak dan abdomen ditutup rambut tebal. Warna rambut pada bagian protorak dan kepala lebih gelap, sedangkan pada bagian dorsal torak terang, putih. Jantan dewasa antena bipektinat cukup panjang, meruncing ke bagian ujung, ruas terakhir tidak bercabang, tunggal. Setiap cabang terdapat dua baris rambut halus sampai ujung. Bentuk sayap depan lebar, dengan mosaik warna putih sampai coklat tua pada bagian dorsal. Bagian ventral sayap coklat polos. Bentang sayap depan $21 \mathrm{~mm}$, dengan sayap belakang segitiga. Abdomen lebih pendek dari pada sayap depan, sisi ventral lebih terang. Duri panjang agak melengkung mengikuti bentuk tibia tungkai depan dengan barisan rambut cukup rapat. Pada sisi dalam berhadapan dengan tibia, unguis sepasang. Betina vermiform, antena, tungkai dan embelan lain vestigial, agak gemuk.

Kantong oval, bagian tengah relatif sedikit lebih besar daripada bagian pangkal dan ujung. Kedudukan kantong melekat kuat langsung pada ranting (tidak menggantung) di salah satu sisi pangkal kantong. Kantong tidak terlalu keras, permukaan tercampur jaringan tumbuhan berupa daun, ranting dengan ukuran beragam. Warna dasar putih, masih terlihat diantara sisa jaringan tanaman, warna kecoklatan, kantong pada pupa jantan lebih pendek (terpenggal) dibandingkan dengan betina yang lebih mengerucut. Kedudukan kantong menempel keras pada tanaman (tidak menggantung bebas).

Tabel (Table) 1. Keberadaan spesies ulat kantong pada sengon di beberapa lokasi (The occurrence of bagworm species on albizia in some areas/districts)

Spsies ulat kantong

(Bagworms species)

Bogor

Pekalongan

Batang

Subang

1. P. plagiophleps

2. C. javana

3. C. crameri

4. K. cuprea

$\sqrt{ }$
$\sqrt{ }$
$\sqrt{ }$
$\sqrt{ }$

$\sqrt{ }-\sqrt{2}$

$\sqrt{1}$

$\sqrt{ }-\sqrt{ }$

$\begin{array}{ll}\sqrt{ } & \sqrt{ } \\ - & - \\ \sqrt{ } & \sqrt{ } \\ \sqrt{ } & -\end{array}$

Keterangan (Remark): $\sqrt{ }=$ Indikasi ada di lokasi tersebut (Indicating occured in the area)

A

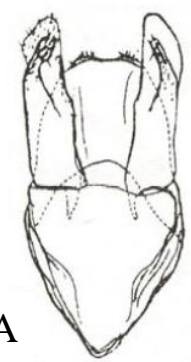

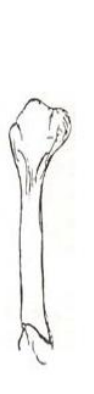

B

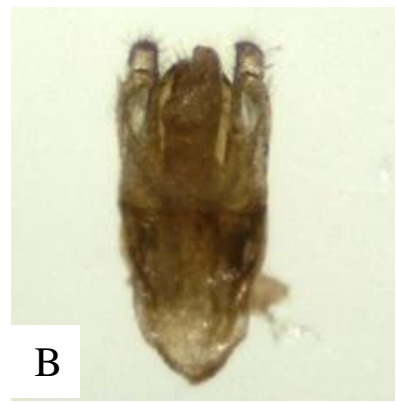

Keterangan (Remark): Ilustrasi dari Shamsudeen dan Mathew (2010) (A) dan foto pribadi (B) (Ilustration from Shamsudeen and Mathew (2010) (A) and personal documentation (B)).

Gambar (Figure) 2. Genetalia jantan P. plagiophleps (Male genetalia of $\underline{\text { P. plagiophleps) }}$ 


\section{c. Clania crameri Westw}

Asal sampel : Bogor, Jawa Barat

Tanggal koleksi : Januari 2019

Inang : Sengon

Deskripsi : Kepala, torak dan abdomen ditutup rambut tebal. Warna umumnya coklat tua, variasi garis longitudinal pada sisi dorsal torak dan bagian dekat pangkal sayap berwarna agak terang. Antena jantan dewasa tipe bipektinat cukup panjang, setiap cabang terdapat dua baris rambut halus sampai ujung. Mata majemuk berpola bintik. Bentang sayap $31 \mathrm{~mm}$, bentuk sayap depan moderat, tidak terlalu panjang atau lebar, warna sayap depan coklat dengan warna agak gelap pada bagian sel dekat percabangan venasi dekat ujung, sayap belakang agak membulat. Bentuk abdomen mengerucut dan panjangnya sedikit atau kurang lebih sama panjang dengan sayapnya, Rambut panjang menutup bagian sampai tibia, duri panjang agak melengkung mengikuti bentuk tibia tungkai depan dengan barisan rambut sangat rapat pada sisi dalam berhadapan dengan tibia, dan unguis sepasang.

Kantong lebih besar daripada C. javana, bentuk dasar oval, permukaan tertutup umumnya dari material ranting yang tersusun arah longitudinal, material sangat beragam, berwarna coklat. Kedudukan kantong menggantung bebas pada tanaman.

\section{d. Kophene cuprea Moore}

Asal sampel : Bogor, Jawa Barat

Tanggal koleksi : Januari 2019

Inang : Sengon

Deskripsi : Kepala, torak dan abdomen ditutupi rambut berwarna coklat terang polos, kekuningan. Antenna bipektinet, dua baris rambut halus di setiap cabangnya. Bentang sayap $20 \mathrm{~mm}$, bentuk sayap depan lebar, abdomen lebih pendek dari sayap belakang, dan unguis sepasang.

Bentuk dasar kantong kerucut memanjang, langsing panjang, kokoh, permukaan halus, polos dengan warna dasar putih sedikit bintik pada bagian ujung distal, lapisan pada bagian pangkal menutup secara tegas, lebih lembut dibandingkan bagian kantong utama, tersambung ke sutera yang terpilin, menggantung pada ranting atau daun, bagian dekat ujung juga lebih lunak.

\section{Musuh alami dan parasitisasi}

Terdapat 11 spesies parasitoid dari enam famili: Ichneumonidae, Eulophidae, Trichogrammatidae, Chalcididae, Braconidae, dan Eurytomidae yang termasuk dalam Ordo Hymenoptera dan satu famili yaitu Tachinidae dari ordo Diptera yang menyerang empat spesies ulat kantong (Tabel 3). Kecuali K. cuprea, setiap spesies ulat kantong diserang lebih dari satu spesies parasitoid. Sebagian besar parasitoid adalah soliter, dan lainnya adalah gregarius seperti Trichogramma sp. Xanthopimpla sp., Pediobius sp., dan lalat tachinid. Beberapa spesies parasitoid tidak hanya menyerang satu spesies inang ulat kantong. Parasitoid Goryphus sp. menyerang ulat kantong P. plagiophleps dan C. crameri sedangkan Eurytoma sp. menyerang C. javana dan C. crameri. Tingkat parasitisasinya disajikan pada Gambar 3. Tiga spesies parasitoid pada ulat kantong $\mathrm{P}$. plagiophleps adalah Goryphus sp., Sympiesis sp., dan Elasmus sp. Tiga spesies parasitoid tersebut muncul secara soliter dan secara bersama parasitisasinya kurang dari $2 \%$. Selain parasitisasinya yang rendah, kelimpahan populasinya juga rendah. 
Tabel (Table) 2. Ukuran kantong beberapa spesies ulat kantong (The size of the bags of several bagworms species)

\begin{tabular}{lcc}
\hline $\begin{array}{c}\text { Spesies ulat kantong } \\
\text { (Bagworms species })\end{array}$ & $\begin{array}{c}\text { Panjang } \pm \text { SD } \\
(\text { Length } \pm S D)(\mathrm{cm})\end{array}$ & $\begin{array}{c}\text { Diameter } \pm \text { SD } \\
(\mathrm{cm})\end{array}$ \\
\hline 1. P. plagiophleps & $0,8 \pm 0,03$ & $0,21 \pm 0,01$ \\
2. C. javana & $1,4 \pm 0,03$ & $0,33 \pm 0,00$ \\
3. C. crameri & $5,3 \pm 0,20$ & $1,40 \pm 0,06$ \\
4. K. cuprea & $2,4 \pm 0,09$ & $0,45 \pm 0,02$ \\
\hline
\end{tabular}

Keterangan (Remark): SD = Standar deviasi (Standard of deviation)

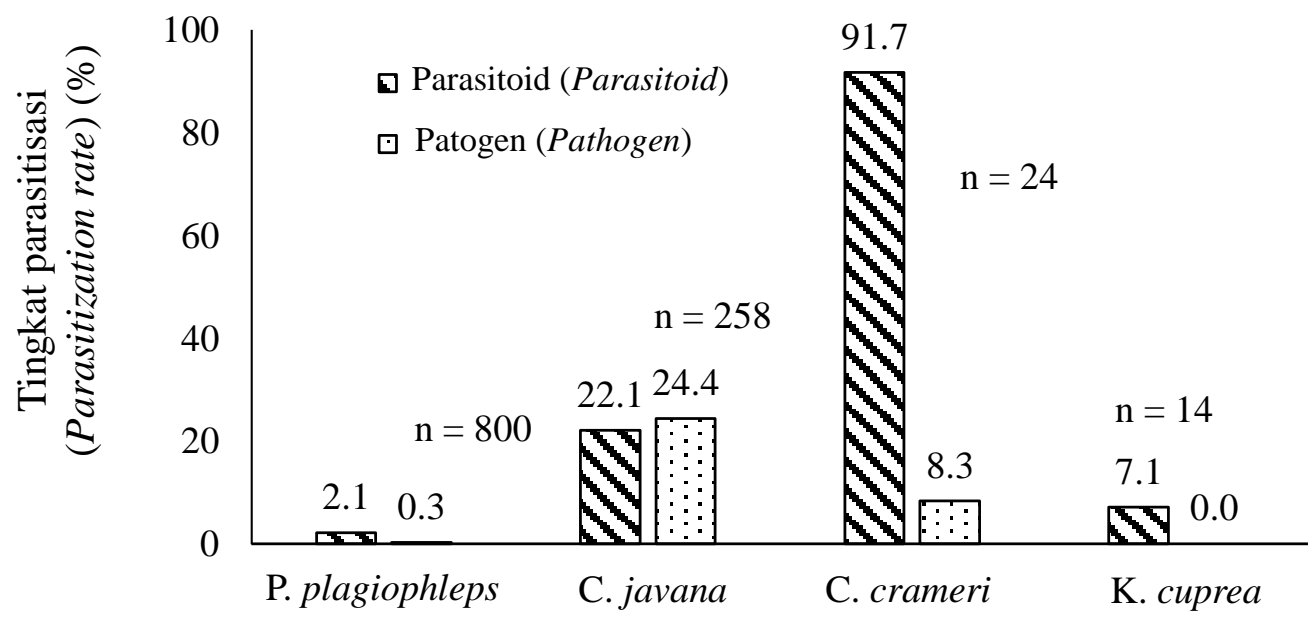

Gambar (Figure) 3. Parasitisasi terhadap ulat kantong oleh parasitoid dan cendawan entomopatogen (Parasitization of bagworms by parasitoids and entomopathogenic fungi) 
Tabel (Table) 3. Musuh alami dan tingkat parasitisasinya terhadap ulat kantong (Natural enemies and the degree of parasization of bagworms species)

\begin{tabular}{|c|c|c|c|}
\hline $\begin{array}{c}\text { Inang dan musuh alami } \\
\text { (Host and natural enemies) }\end{array}$ & $\begin{array}{c}\text { Parasitisasi } \\
\text { (Parasitization) } \\
(\%)\end{array}$ & $\sum_{\left(\sum \text { Individual }\right)}$ & $\begin{array}{c}\text { Keterangan } \\
\text { (Remarks) }\end{array}$ \\
\hline \multicolumn{4}{|l|}{ P. plagiophleps $(\mathrm{n}=800)$} \\
\hline Parasitoid (Parasitoids): & & & \\
\hline - Goryphus sp. & 0,9 & 7 & S \\
\hline - Sympiesis sp. & 0,3 & 2 & $\mathrm{~S}$ \\
\hline - Elasmus sp. & 0,1 & 1 & $\mathrm{~S}$ \\
\hline $\begin{array}{l}\text { - Tidak teridentifikasi (Not } \\
\text { identified) }\end{array}$ & 0,9 & - & - \\
\hline $\begin{array}{l}\text { Patogen (Pathogen): } \\
\text { - Peacilomyces sp. }\end{array}$ & 0,3 & - & - \\
\hline
\end{tabular}

C. javana $(\mathrm{n}=258)$

Parasitoid (Parasitoids):

- Spathius sp.

$\begin{array}{ccc}0,4 & 1 & \mathrm{~S} \\ 20,5 & 53 & \mathrm{~S} \\ 0,4 & 5 & \mathrm{~K} \\ 0,4 & 1 & \mathrm{~S} \\ 0,4 & 1 & \mathrm{~S}\end{array}$

- Brachymeria carinata

- Trichogramma sp.

- Cotesia metesae

- Eurytoma sp.

S

Patogen (Pathogen):

- Beauveria bassiana

24,4

C. crameri $(\mathrm{n}=24)$

Parasitoid (Parasitoids):

- Xanthopympla sp.

$\begin{array}{ccc}8,3 & 16 & \mathrm{~K} \\ 4,2 & 1 & \mathrm{~S} \\ 4,2 & 26 & \mathrm{~K} \\ 4,2 & 1 & \mathrm{~S} \\ 20,8 & 16 & \mathrm{~K} \\ 50,0 & - & -\end{array}$

- Goryphus sp.

- Pediobius sp.

- Eurytoma sp.

- Lalat tachinid

- Tidak teridentifikasi (Not identified)

Patogen (Pathogen):

- Beauveria bassiana

8,3

K. cuprea $(\mathrm{n}=14)$

Parasitoid (Parasitoids):

- Tidak teridentifikasi (Not identified)

Patogen (Pathogen):

Keterangan (Remark): S = Solo (Solitary), K = Kelompok (Gregarius)

Parasitisasi pada C. javana sebesar 24,8\%. Brachymeria carinata adalah parasitoid yang muncul secara soliter dan paling dominan $(20,5 \%)$. Kemunculan parasitoid ini umumnya meninggalkan lubang pada salah satu sisi kantong. Adapun kelimpahan dan parasitisasi parasitoid lainnya; Spathius sp., Trichogramma sp., Cotesia metesae, dan Eurytoma sp. rendah. 
Parasitoid dari kelompok Hymenoptera dan tingkat parasitisasinya yang menyerang C. crameri adalah Xanthopympla sp. (8,3\%), Goryphus sp. (4,6\%), Paediobius sp. $(4,16 \%)$, dan Eurytoma sp. (4,16\%). Selain itu parasitisasi juga terjadi karena lalat tachinid (Diptera) yang mencapai 20,8\%. Parasitoid Xanthopympla sp., Pediobius sp., dan lalat tachinid merupakan parasitoid gregarious, sehingga kelimpahannya lebih tinggi dibandingkan spesies parasitoid lainnya. Tidak ada parasitoid atau cendawan entomopatogen yang berhasil diidentifikasi dari sejumlah 14 sampel ulat kantong K. cuprea yang ditemukan. Hanya satu sampel yang diduga bekas parasitoid.

Dua individu P. plagiophleps ditemukan mati dengan gejala kantong yang tertutup cendawan berwarna putih dan kemudian diisolasi dan diidentifikasi sebagai Peacilomyces sp. Selain itu, sebanyak 63 individu C. javana dan dua individu C. crameri juga ditemukan mati dengan gejala yang sama. Namun cendawan pada dua spesies ulat kantong tersebut diidentifikasi sebagai B. bassiana.

\section{B. Pembahasan}

Terdapat beberapa spesies ulat kantong yang dilaporkan berasosiasi dengan sengon. Spesies tersebut berasal dari beberapa genera yaitu Pteroma, Cryptothelea, Amatissa, dan Clania. Selain itu masih ada beberapa morfospesies yang belum berhasil diidentifikasi (Lelana \& Anggraeni, 2012; Anggraeni \& Ismanto, 2013; Setyawan, Hidayat, \& Puliafico, 2018).

Salah satu persoalan yang sering dijumpai dalam identifikasi yang berbasis morfologi adalah berkaitan dengan sulitnya identifikasi pada karakter penting misalnya organ genetalia dan adanya perubahan fenotip (phenotipic plasticity) akibat faktor lingkungan, misalnya makanan (Lunardi, Benítez, Câmara, Gomes, \& Arrais-Silva, 2017) atau suhu (Wang, Yang, Han, Fan, \& Zhao, 2014). Akibatnya, spesies yang sama dapat diidentifikasi sebagai spesies yang berbeda. Namun saat ini identifikasi suatu spesies dapat dilakukan melalui pendekatan molekuler yang mampu mengkonfirmasi identitas spesies yang berbeda termasuk adanya sinonimi (Tahir, Noor, Mehmood, Sherawat, \& Qazi, 2018; Zhao, Jiufeng, Wenjun, Guoqing, \& Zhang, 2018).

Beberapa spesies ulat kantong yang pernah dipublikasikan, merupakan sinonim satu sama lain. Clania dan Cryptothelea menurut Moore, (1882) adalah dua genera yang bersinonim termasuk didalamnya adalah Eumeta crameri, Oiketicus cramerii, Cryptothelea consorta, dan Eumeta nietneri. Department of Agriculture and Water Resources, (2019) menyebutkan bahwa Clania, Eumeta, dan Cryptothelea juga bersinonim sebagaimana pada spesies Clania $(=$ Eumeta $=$ Cryptothelea) variegata. Namun menurut Anggraeni \& Ismanto, (2013), Clania dan Eumeta disebutkan sebagai jenis yang berbeda. Hal ini disebabkan karena basis identifikasi yang digunakan pada penelitian tersebut hanya berdasarkan karakter kantong secara kualitatif.

Ulat kantong Amatissa sp. yang diidentifikasi oleh Lelana \& Anggraeni, (2012) kemungkinannya adalah sinonim Kophene. Dalam penelitian ini diidentifikasi sebagai Kophene cuprea berdasarkan kesamaan visual ciri kantongnya. Sinonim lainnya adalah Bambalina yang habitatnya ditemukan di daerah Kalkuta, India dengan ciri yang menonjol adalah warna coklat terang dengan semburat keemasan dengan bentang sayap sekitar $24 \mathrm{~mm}$ (Hampson, 1892).

Ulat kantong Chalia javana bersinonim dengan Oiketicoides javana. Spesies ini juga memiliki sinonim lainnya yaitu Mahasena destructor dan Lansdownia bifenestralis, termasuk Clania. Spesies-spesies ini sebaran alaminya berada di Jawa (Sobczyk, 2011). Adapun Pteroma juga bersinonim dengan Acanthopsyche (Hampson, 1892). 
Jumlah sampel yang rendah khususnya pada C. crameri dan K. cuprea dapat terkait sifat biologi yang berbeda seperti siklus hidup dan tingkat kematian ulat kantong. Ada peluang bahwa fase pupasi tidak bersamaan dengan periode pengambilan sampel karena siklus hidup yang berbeda. Siklus hidup P. plagiophleps berkisar 40-88 hari sedangkan siklus hidup C. crameri lebih lama berkisar 84-365 hari, demikian juga fekunditasnya berbanding lurus (Rhainds, Davis, \& Price, 2009). Meskipun fekunditasnya tinggi, peran musuh alami, termasuk parasitoid dapat menekan populasinya, sehingga hal ini diduga menjadi salah satu sebab rendahnya jumlah sampel yang dapat dikumpulkan dari lapangan.

Parasitisasi dapat lebih tinggi atau rendah dipengaruhi oleh populasi ulat kantong sebagai inangnya (Mahadi, Muhamad, \& Adam, 2012). Rendahnya parasitisasi pada P. plagiophleps dimungkinkan populasinya pada periode ini cukup rendah dibandingkan periode lain, meskipun demikian pada penelitian ini perbedaan populasi tersebut tidak dikaji. Spesies ulat kantong juga berasosiasi dengan parasitoid yang berbeda, misalnya parasitoid gregarius cenderung memarasit ulat kantong yang berukuran lebih besar seperti C. javana dan C. crameri demikian juga dengan ukuran tubuh parasitoid pada dua spesies ulat kantong tersebut berukuran lebih besar. Hal ini menunjukkan adanya preferensi parasitoid terhadap inangnya. Menurut (Liu, Xu, Li, \& Sun, 2011), pemilihan inang yang lebih besar akan meningkatkan keberhasilan generasi selanjutnya.

Kelimpahan jenis musuh alami dan parasitisasinya yang rendah pada ulat kantong P. plagiophleps. Rendahnya parasitisasi juga pernah dilaporkan pada P. pendula. Meskipun parasitisasi tidak dipengaruhi oleh faktor cuaca, secara temporal parasitisasi berfluktuasi dan dipengaruhi oleh populasi inangnya (ulat kantong) (Mahadi, Muhamad, \& Adam, 2012) Faktor lain yang memengaruhi parasitisasi adalah keberadaan tumbuhan berguna (Kamarudin \& Basri 2010; Kamarudin \& Arshad 2016). Meskipun demikian pada penelitian ini masih perlu dibuktikan. Selain parasitisasinya, kelimpahan parasitoid ulat kantong juga mengalami fluktuasi secara temporal (Putra, Pudjianto, \& Maryana, 2016).

Spesies parasitoid yang kelimpahan populasinya cukup tinggi adalah B. carinata pada ulat kantong C. javana yang muncul secara soliter. Parasitoid ini juga dilaporkan memarasit ulat kantong Metisa plana (Potineni \& Saravanan 2013; Halim et al., 2017; Halim et al., 2018).

Parasitoid lalat Tachinidae cukup dominan pada C. crameri (20,8\%). Kelompok lalat ini juga dilaporkan sebagai parasitoid penting pada beberapa spesies ulat kantong lainnya (Hanysyam et al., 2013; Pamuji, Rahardjo, \& Tarno, 2013; Baudino, Martínez, Fernández, Geist, Gallardo, \& Reimer, 2017; El Husseini \& Askar, 2019).

Sebagian sampel yang dikumpulkan sudah kosong dan meninggalkan tanda berupa lubang pada salah satu sisi kantong atau bekas puparium didalamnya. Hal ini lazim ditemukan pada beberapa sampel ulat kantong P. plagiophleps, C. crameri, dan K. cuprea.

Cendawan Peacilomyces merupakan entomopatogen yang cukup penting pada ulat kantong P. pendula (Cheong, Sajap, Hafidzi, Omar, \& Abood, 2010). Meskipun demikian tingkat infeksinya terhadap P. plagiophleps pada penelitian ini masih rendah. Cendawan entomopatogen lainnya adalah B. bassiana. Cendawan ini sudah dikenal luas dan digunakan komersial sebagai agens pengendali biologis berbagai serangga hama (Mascarin \& Jaronski, 2016). Seperti halnya pada C. javana, cendawan B. bassiana juga menyebabkan mortalitas yang tinggi pada ulat kantong P. pendula (Tajuddin, Ali, Bakeri, \& Kamaruzzaman, 2010) dan M. plana (Sitompul \& Lazuardi, 2014), namun cendawan ini hanya memarasit dua individu C. crameri. 


\section{KESIMPULAN DAN SARAN}

\section{A. Kesimpulan}

Spesies ulat kantong yang menyerang sengon adalah P. plagiophleps, C. javana, C. crameri, dan K. cuprea. Spesies P. plagiophleps populasinya paling dominan. Setiap spesies memiliki kantong yang khas sebagai penanda spesies, baik bentuk maupun ukurannya. Terdapat banyak kerancuan identifikasi terhadap spesies ulat kantong yang disebabkan oleh pendekatan metode identifikasi yang berbeda dan tidak lengkap, sehingga memunculkan sinonimi. Musuh alami ulat kantong umumnya adalah parasitoid dari Ordo Hymenoptera dan Diptera dan mikroba entomopatogen. Parasitisasi terhadap ulat kantong P. plagiophleps relatif rendah namun pada C. javana dan C. crameri cukup tinggi.

\section{B. Saran}

Penelitian identifikasi perlu diperkuat berdasarkan basis molekuler sekaligus morfologinya (kantong, imago, termasuk larva) untuk mengurangi kerancuan dalam menentukan identitas spesies termasuk sinonim. Selain itu penelitian yang lebih mendalam perlu dilakukan secara temporal dan spasial yang menyangkut berbagai pengaruh variabel seperti elevasi, musim, maupun asosiasi dengan vegetasi sekitar tegakan.

\section{UCAPAN TERIMA KASIH}

Terima kasih kepada Lembaga Pengelola Dana Pendidikan (LPDP), Kementerian Keuangan Repubik Indonesia atas bantuan dana dalam penelitian ini dan Kelompok Peneliti Perlindungan Hutan, Pusat Penelitian dan Pengembangan Hutan, Badan Penelitian, Pengembangan, dan Inovasi, Kementerian Lingkungan Hidup dan Kehutanan.

\section{DAFTAR PUSTAKA}

Anggraeni, I., \& Ismanto, A. (2013). Keanekaragaman jenis ulat kantong yang menyerang di berbagai pertanaman sengon (Paraserianthes falcataria (L.) Nielson) di Pulau Jawa. Jurnal Sains Natural Universitas Nusa Bangsa, 3(2), 184192.

[BPS] Badan Pusat Statistik. (2019). Statistik Produksi Kehutanan 2018. Jakarta.

Baudino, E.M., Martínez, J.J., Fernández, L., Geist, Y.H., Gallardo, H.E., \& Reimer, A. (2017). Parasitoides del bicho canasto, Oiketicus platensis (Lepidoptera: Psychidae) en el caldenal pampeano. Revista de Investigaciones Agropecuarias, 43(3), 291-296.

Brothers, D.J., Finnamore, A.T., Gibson, G.A.P., Goulet, H., Huber, J.T., Masner, L., ... Wahl, D.B. (1993). Hymenoptera of the world: An identification guide to families. $(\mathrm{H}$. Goulet \& Huber, J.T. Eds.). Ottawa, Ontario: Centre for Land and Biological Resources, Research Branch Agriculture Canada. https://doi.org/10.1093/ae/40.2.115

Cheong, Y.L., Sajap, A.S., Hafidzi, M.N., Omar, D., \& Abood, F. (2010). Outbreaks of bagworms and their natural enemies in an oil palm, Elaeis guineensis, plantation at Hutan Melintang, Perak, Malaysia. Journal of Entomology, 7(3), 141-151. https: //doi.org/10.3923/je.2010.141.151

Department of Agriculture and Water Resources. (2019). Final Report for The Review of Biosecurity Import Requirements for Fresh Longan Fruit from Vietnam. Canberra, Australia.

El Husseini, M.M., \& Askar, S.I. (2019). The bagworm, Amicta quadrangularis Christoph, and its natural enemies in northern Egypt (Lepidoptera: Psychidae). Egyptian Journal of Biological Pest Control, 29(1), 1-4. https://doi.org/10.1186/s41938-0190127-7

Frank, K.D. (2015). Bag worm (Thyridopteryx ephemeraeformis). In 
Ecology of Center City, Philadelphia (p. 33). Philadelphia: Fitler Square Press.

Halim, M., Muhaimin, A.M.D., Zulaikha, S.A., Atikah, A.R.N., Masri, M.M. M., \& Yaakop, S. (2017). Evaluation of infestation in parasitoids on Metisa plana Walker (Lepidoptera: Psychidae) in three oil palm plantations in peninsular Malaysia. Serangga, 22(2), 135-149.

Halim, Madihah, Zuki, A., Ahmad, S.Z., Din, A.M., Rahim, A., Masri, M.M., ... Yaakop, S. (2018). Exploring the abundance and DNA barcode information of eight parasitoid wasps species (Hymenoptera), the natural enemies of the important pest of oil palm, bagworm, Metisa plana (Lepidoptera: Psychidae) toward the biocontrol approach and it's application in Malaysia. Journal of Asia-Pacific Entomology, 21(4), 1359-1365. https://doi.org/10.1016/ j.aspen.2018.10.012.

Hampson, G.F. (1892). The Fauna of British India, including Ceylon and Burma (Vol. I). (Blanford, W.T. Ed.). London: Taylor and Francis. https: //doi.org/10.5962/bhl.title.100738

Hanysyam, M.N., Fauziah, I., Khairiyah, M.H.S., Fairuz, K., Rasdi, Z.M., Zfarina, M. Z.N., ... Norazliza, R. (2013). Entomofaunal diversity of insects in FELDA gunung besout 6 , Sungkai, Perak. In BEIAC 2013-2013 IEEE Business Engineering and Industrial Applications Colloquium, 234-239. https://doi.org/10.1109/ BEIAC.2013.6560123

Kamarudin, N., \& Arshad, O. (2016). Diversity and activity of insect natural enemies of the bagworm (Lepidoptera: Psychidae) within an oil palm plantation in Perak, Malaysia. Journal of Oil Palm Research, 28(3), 296-307. https://doi.org/10.21894/jopr.2803.06

Kamarudin, N., \& Wahid, M.B. (2010). Interactions of the bag worm,
Pteroma pendula (Lepidoptera: Psychidae), and its natural enemies in an oil palm plantation in perak. Journal of Oil Palm Research, 22, 758-764.

Lelana, N.E., \& Anggraeni, I. (2012). An outbreak of bagworms on Falcataria molluccana: a case study in Central Java. In Mohammed, C., Beadle, C., Roux, J., \& Rahayu, S. (Eds.), Proceeding of International Conference on The Impacts of Climate Change to Forest Pests and Diseases in The Tropics, 99-103. Yogyakarta: Faculty of Forestry, Universitas Gadjah Mada.

Liu, Z., Xu, B., Li, L., \& Sun, J. (2011). Host-Size mediated trade-off in a parasitoid Sclerodermus harmandi. PLoS ONE, 6(8), 1-11. https://doi.org/10.1371/journal.pone.0 023260

Lunardi, R.R., Benítez, H.A., Câmara, T.P., Gomes, L.P., \& Arrais-Silva, W.W. (2017). Head shape variation in response to diet in Triatoma williami (Hemiptera, Reduviidae: Triatominae), a possible chagas disease vector of legal amazônia. Zoologischer Anzeiger, 267, 187-193. https://doi.org/10.1016/j.jcz.2017.04.0 01

Mahadi, N.A., Muhamad, R., \& Adam, N.A. (2012). Relationship between bagworm Pteroma pendula Joannis (Lepidoptera: Psychidae) populations, parasitoids, and weather parameters in oil palm plantation. Journal of Agricultural Science, 4(12), 13-17. https://doi.org/10.5539/jas.v4n12p13

Mascarin, G.M., \& Jaronski, S.T. (2016). The production and uses of Beauveria bassiana as a microbial insecticide. World Journal of Microbiology and Biotechnology, 32(11), 1-26. https://doi.org/10.1007/s11274-0162131-3

Moore, F. (1882). The Lepidoptera of Ceylon (Vol. II). London: L Reeve \& Co. https://doi.org/10.1007/978-94- 
011-0745-7_246

Pamuji, R., Rahardjo, B.T., \& Tarno, H. (2013). Populasi dan serangan hama ulat kantung Metisa plana Walker (Lepidoptera: Psychidae) serta parasitoidnya di perkebunan kelapa sawit Kabupaten Donggala, Sulawesi Tengah. Jurnal HPT, 1(2), 58-71. https://doi.org/10.5268/IW-6.2.982

Putra, I.L.I., Pudjianto, \& Maryana, N. (2016).

Keanekaragaman Hymenoptera parasitoid pada perkebunan kelapa sawit PTPN VIII Cindali, Bogor. Jurnal Hama dan Penyakit Tumbuhan Tropika, 16(2), 165. https://doi.org/10.23960/j.hptt. 216165-174

Rhainds, M., Davis, D.R., \& Price, P.W. (2009). Bionomics of bagworms (Lepidoptera: Psychidae). Annual Review of Entomology, 54(1), 209226. https://doi.org/10.1146/ annurev.ento.54.110807.090448

Setyawan, Y.P., Hidayat, P., \& Puliafico, K. P. (2018). Herbivorous insects associated with albizia (Falcataria moluccana) saplings in Bogor. In IOP Conference Series: Earth and Environmental Science, 197, 1-8. Bogor. https://doi.org/10.1088/17551315/197/1/012018

Shamsudeen, R.S.M., \& Mathew, G. (2010). Taxonomy studies on the sub family Psychinae (Lepidoptera: Psychidae) of Kerala, India. World Journal of Zoology, 5(4), 330-331.

Sitompul, U.C., \& Lazuardi. (2014). Pengaruh jamur Bauveria bassiana sebagai pengendalian hayati terhadap mortalitas hama ulat kantung (Metisa plana Walker). In Prosiding Seminar Nasional Biologi dan Pembelajarannya, Jurusan Biologi, FMIPA, Universitas Negeri Medan, 287-296.

Sobczyk, T. (2011). World Catalogue of Insects: Psychidae (Vol 10: Lepidoptera). (Nuss, M., Ed.). Stenstrup, Denmark: Apollo Books Aps.
Sugiura, S. (2016). Bagworm bags as portable armour against invertebrate predators. Peer J., 2, 1-14. https://doi.org/10.7717/peerj.1686

Tahir, H.M., Noor, A., Mehmood, S., Sherawat, S.M., \& Qazi, M.A. (2018). Evaluating the accuracy of morphological identification of insect pests of rice crops using DNA barcoding. Mitochondrial DNA Part B, 3(2), 1220-1224. https://doi.org/ 10.1080/23802359.2018.1532334

Tajuddin, N.S.A., Ali, S.R.A., Bakeri, S.A., \& Kamaruzzaman, N.E. (2010). Effect of Beauveria brongniartii and B. bassiana on oil palm bag worm, Pteroma pendula Joannis. Journal of Oil Palm Research, 22, 729-735.

Usha, A.U., \& Jose, J. (2018). Bag morphology of commonly occurring bagworms (Family: Psychidae) in Kerala - a taxonomic tool. In Faunal Diversity and Recent Trends in Animal Taxonomy. 118-121.

Wang, L., Yang, S., Han, L., Fan, D., \& Zhao, K. (2014). Phenotypic plasticity of HSP70s gene expression during diapause: Signs of evolutionary responses to cold stress among soybean pod borer populations (Leguminivora glycinivorella) in northeast of China. PLOS ONE, 9(10), 1-10. https://doi.org/10.1371/ journal.pone.0109465

Zhao, Q., Jiufeng, W., Wenjun, B., Guoqing, L., \& Zhang, H. (2018). Synonymize Arma chinensis as Arma custos based on morphological, molecular and geographical data. Zootaxa, 4455(1), 161-176. https:// doi.org/10.11646/zootaxa.4455.1.7 